\title{
Experimental Investigation on Exhaust Emission of Direct Injection Diesel Engine Fuelled with Karanja Methyl Ester, Neem Methyl Ester \& Diesel oil
}

\author{
Lokesh Pandey, Department of Mechnical Engineering, DIET Rishikesh, Uttrakhand, India
}

\begin{abstract}
Engrgy crisis due to increase in vehicular use and power demand has led to search for an alternative fuel which is renewable and sustainable. The best possible substitute for diesel is biodiesel. With no or fewer modifications, Diesel engines can be made to run on biodiesel which leads to sustainable reduction in exhaust emissions. In this paper, investigations were carried out to study the exhaust emissions of diesel engine using ternary blends of Karanja methyl ester, Neem methyl ester and Diesel oil. A single cylinder, four stroke, water cooled diesel engine fitted with eddy current dynamometer was used. Initially the engine was run with Diesel fuel (BO) and then with ternary blends (B10, B20, B30, B40, B50). Exhaust emissions (CO, NOx and CO2) were measured by a flue gas analyzer. Test was conducted over entire range of engine operation at varying conditions of load. The experimental results prove that the ternary blends of Karanja methyl ester, Neem methyl ester and diesel oil can be used in diesel engine as fuel to reduce emission.
\end{abstract}

Keywords -Biodiesel, Blending, Diesel engine, Karanja methyl ester, Neem methyl ester

\section{INTRODUCTION}

$\mathrm{T}$ he demand for energy has grown very quickly in recent years due to the rapid development of certain growing economies like India. It is difficult to predict availability of these resources in future, resulting in uncertainty in its supply because fossil fuel reserves are depleting at a faster rate.The decrease of fossil fuel resources such as coal, petroleum, and natural gas has encouraged researchers to develop new approaches to find or invent renewable fuel. Therefore an alternative, cheaper fuel is required to fulfill the needs of men and at the same time it will save more foreign exchange. The environmental issues concerned with the exhaust gases emission by the usage of fossil fuels also encourage the usage of biodiesel, which has proved to be eco friendly far more than fossil fuels. In particular biodiesel has received wide attention as a replacement for diesel fuel because it is biodegradable, nontoxic and can significantly reduce toxic emissions and overall life cycle emission of $\mathrm{CO}_{2}$ from the engine. Biodiesel fuels are considered as replacement for diesel and have a

Lokesh Pandey is working as an assistant professor in Department of Mechanical Engineering in DIET Rishikesh, number of advantages such as higher cetane number and lower emissions of carbon dioxide. Among the non-edible seeds produced in India, Karanja and Neem are most preferred because of their high oil content and biodiesel yield. By transesterification process Karanja and Neem oil can be converted into biodiesel and viscosity can be reduced by this process. The purpose of internal combustion engine is to produce power and to convert it in a useable form. In internal combustion engine the combustion of fuel takes place inside the cylinder. Power produced from engine is mechanical power which is transformed to drive the engine by a crankshaft. There is also other engine parts which are connected to crankshaft as cam shaft etc. The speed of cam shaft is half than that of crank shaft. Cam shaft is used to open and close the valve so that the fuel may be inlet and exhaust gases may be outlet through the valves. In ancient times boats, carts etc. were used for transportation purposes and for travelling purposes but due to development of IC engine the mode of transportation has changed and a valuable time has saved by using high speed engines. IC engines were developed in $18^{\text {th }}$ century when they were invented and the development was done by various engineers. The invention of IC engine has made our life a lot easy compared to the life of ancient times. IC engine are developed through various stages. In IC engine the fuel may be diesel or air according to use. As the IC engines have made our life a lot easy but they have also caused a loss to our environment by causing air pollution. The air pollution has caused various dieses to mankind such as asthma, skin cancer etc. As the IC engines have saved our time but this has made environment a polluting space. Various air pollutants have made our clean environment a harmful place to live in. The improvement of IC engine is at a rapid pace and many other factors are improving. Now bio fuel are being extensively used in IC engine and they have made our environment a less polluting by exhausting less harmful gases in the environment. Bio fuels are environment friendly and as they are extracted from plants they have less polluting matters. It can be said that it is a very good substitute for diesel or petrol and a large scale production of it will be benefitted for both for us and for our environment. 


\section{EXPERIMENTAL SETUP}

The experiment has been conducted on a single cylinder, four stroke and direct injection vertical diesel engine. The load applied by means of electrical loading device. The engine is provided with suitable connections for water cooling and lubrication. The schematic arrangement of experimental setup is shown in Fig 1.

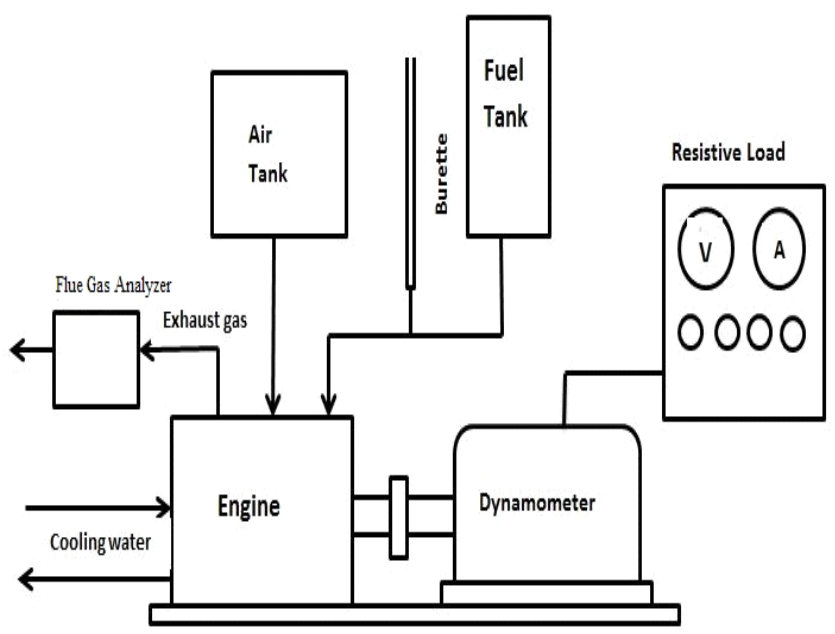

Fig. 1. Experimental Setup

TABLE I

DETAILS SPECIFICATION OF THE ENGINE

\begin{tabular}{cll}
\hline \hline S.No. & \multicolumn{1}{c}{ Configuration } & \multicolumn{1}{c}{ Model } \\
\hline 1 & Make & Kirloskar \\
2 & BHP & $5 \mathrm{HP}$ \\
3 & Speed & $1500 \mathrm{rpm}$ \\
4 & No. of cylinders & One \\
5 & Compression ratio & $18: 1$ \\
6 & Stroke length & $110 \mathrm{~mm}$ \\
7 & Bore & $80 \mathrm{~mm}$ \\
8 & Injection type & Direct injection \\
9 & Loading device & Eddy current \\
& & dynamometer \\
10 & Method of starting & Manual crank shaft \\
11 & Method of cooling & Water \\
12 & Type of ignition & Compression ignition \\
\hline \hline
\end{tabular}

In the experiment different blends have been prepared by blending Karanja oil methyl ester (KOME) and Neem oil methyl ester (NOME) in different proportions with diesel and the entire experiment has been carried out under steady state condition of the engine.

The blends on which the experiment was conducted are following.

1) B 10- 5\% KOME +5\% NOME + 90\% diesel

2) B20-10\% KOME +10\% NOME+ $80 \%$ diesel

3) $\mathrm{B} 30-15 \% \mathrm{KOME}+15 \% \mathrm{NOME}+70 \%$ diesel

4) B $40-20 \% \mathrm{KOME}+20 \% \mathrm{NOME}+60 \%$ diesel

5) B50- $25 \% \mathrm{KOME}+25 \% \mathrm{NOME}+50 \%$ diesel

Results have been compared with those obtained by using $100 \%$ diesel oil.

Initially the readings were taken on engine running with diesel, then diesel was replaced by ternary blends (B10, B20, $\mathrm{B} 30, \mathrm{~B} 40$ and B50) and readings were recorded. There is no engine modification when ternary blends are tested on engine. Red wood viscometer was used to determine viscosity of the fuel and a density bottle was used to find the density of the fuel.

Engine emissions such as carbon monoxide (CO), carbon dioxide $\left(\mathrm{CO}_{2}\right)$ and nitrogen oxides (NOx) were measured with ECOMD flue gas analyzer. The sensor of the analyzer was exposed to the engine exhaust and the observations were recorded for all blends. The measured emissions were analyzed under different loads.

\section{RESULTS AND DISCUSSION}

The results obtained from the experimental investigations are analyzed and described below.

\section{A. Load vs Carbon Monoxide}

The emission of Carbon monoxide is decreasing with increasing load for diesel and ternary blends. $\mathrm{CO}$ emission at full load for diesel is $667 \mathrm{mg} / \mathrm{m} 3$. However for blends of $\mathrm{B} 10$, $\mathrm{B} 20, \mathrm{~B} 30, \mathrm{~B} 40$ and $\mathrm{B} 50, \mathrm{CO}$ emission is continuously decreasing and is 550, 484, 340, 328 and $226 \mathrm{mg} / \mathrm{m} 3$ respectively at full load. At full load, the percentage reduction in $\mathrm{CO}$ emission for B10, B20, B30, B40 and B50 is $17.54 \%$, $27.43 \%, 49.02 \%, 50.82 \%$ and $66.11 \%$ respectively. B50 gives lowest $\mathrm{CO}$ emission as compared to other blends for entire range of load.

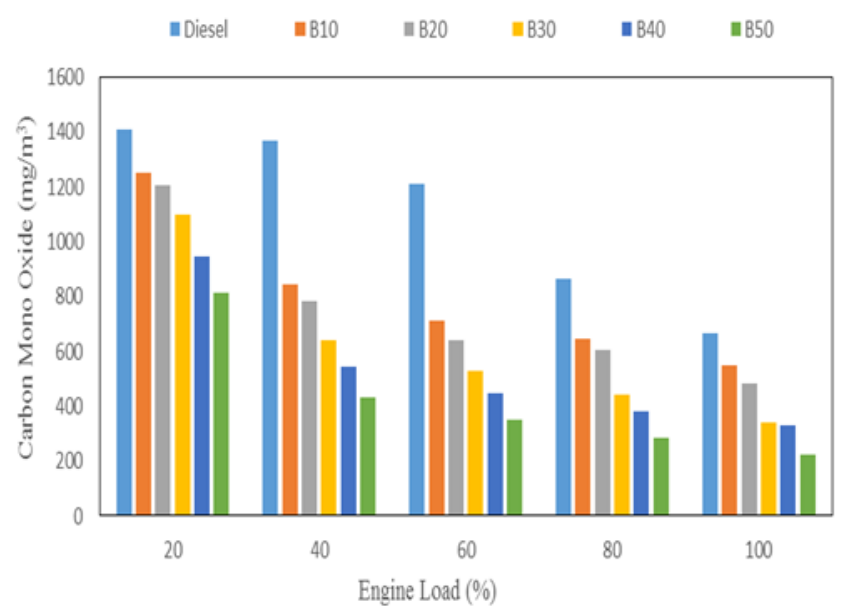

Fig. 2. Load vs Carbon Monoxide

\section{B. Load vs Oxides of Nitrogen}

NOx emission for diesel at full load is $155 \mathrm{mg} / \mathrm{m} 3$ and for blends of B10, B20, B30, B40 and B50 it is 161,172,180,170 and $178 \mathrm{mg} / \mathrm{m} 3$ respectively. Increment in NOx at full load for B10, B20, B30, B40 and B50 is $3.87 \%, 10.96 \%, 16.12 \%$, $9.67 \%$ and $14.83 \%$ Increase in NOx emission for B10 is minimum as compared to other blends. 
Proc. of the Sixth Intl. Conf. Advances in Civil, Structural and Mechanical Engineering - CSM 2018 Copyright (C) Institute of Research Engineers and Doctors, USA. All rights reserved.

ISBN: 978-1-63248-150-4 doi: 10.15224/978-1-63248-150-4-49

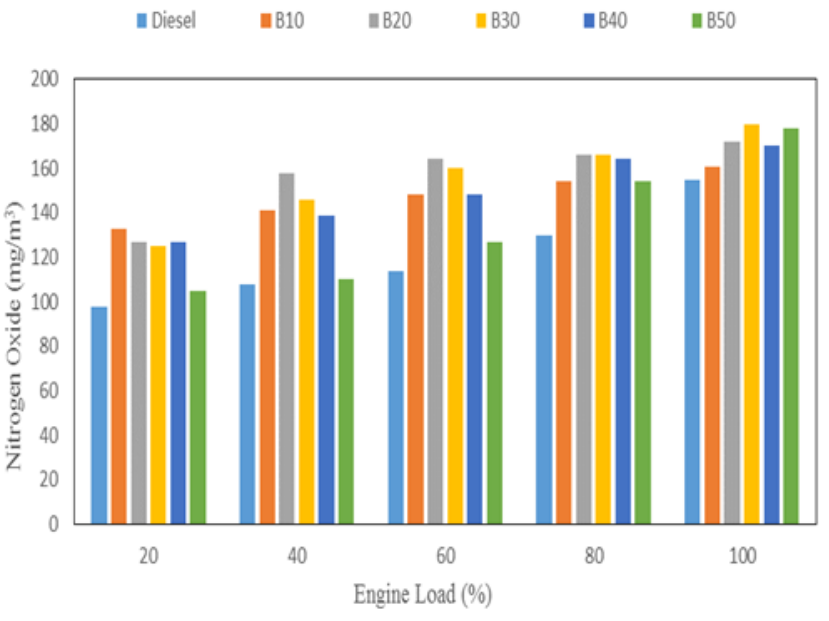

Fig. 3. Load vs Nitrogen oxide

\section{Load vs Carbon Dioxide}

The emission of carbon dioxide is decreasing with increase in load. $\mathrm{CO} 2$ emission is $3 \%$ for diesel at full load. For blends $\mathrm{B} 10, \mathrm{~B} 20, \mathrm{~B} 30, \mathrm{~B} 40$ and $\mathrm{B} 50, \mathrm{CO} 2$ it is $2.3 \%, 2.1 \%, 1.8 \%$, $1.6 \%$ and $1.1 \%$. The decrease in emission is $23.33 \%, 30 \%$, $40 \%, 46.66 \%$ and $63.33 \%$ respectively at full load as compared to diesel. For entire range of load, $\mathrm{CO} 2$ emission for $\mathrm{B} 50$ is lower than diesel and other blends.

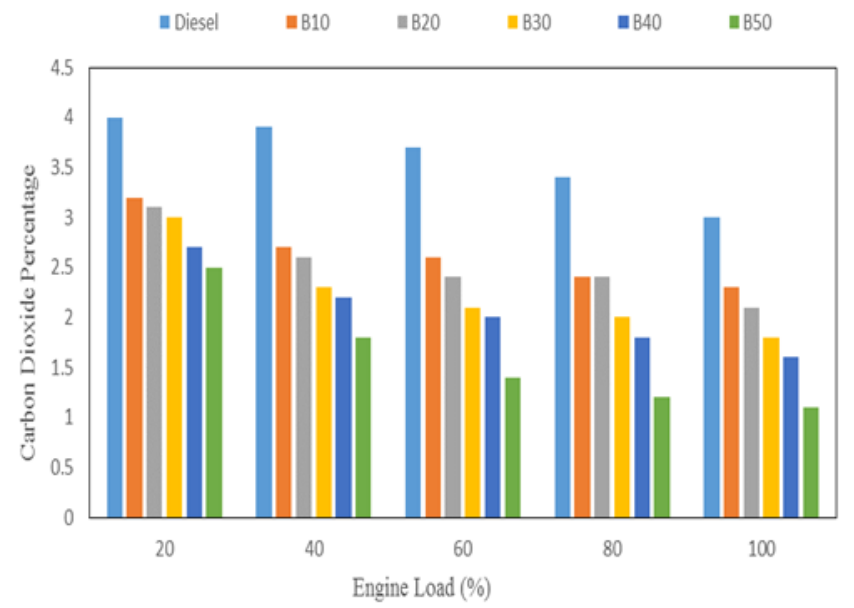

Fig. 4. Load vs Carbon Dioxide

\section{Load vs Brake Horse Power}

The brake horse power for diesel is 2.569. For blends, B10, B20, B30, B40 and B50, it is 2.218, 2.287, 2.201, 2.184 and 2.201 at full load. From $40 \%$ to $60 \%$ load, there is a sharp increase in bhp for diesel as well as for all blends. Data shows that at higher loads, B20 values are greater than that of other blends.

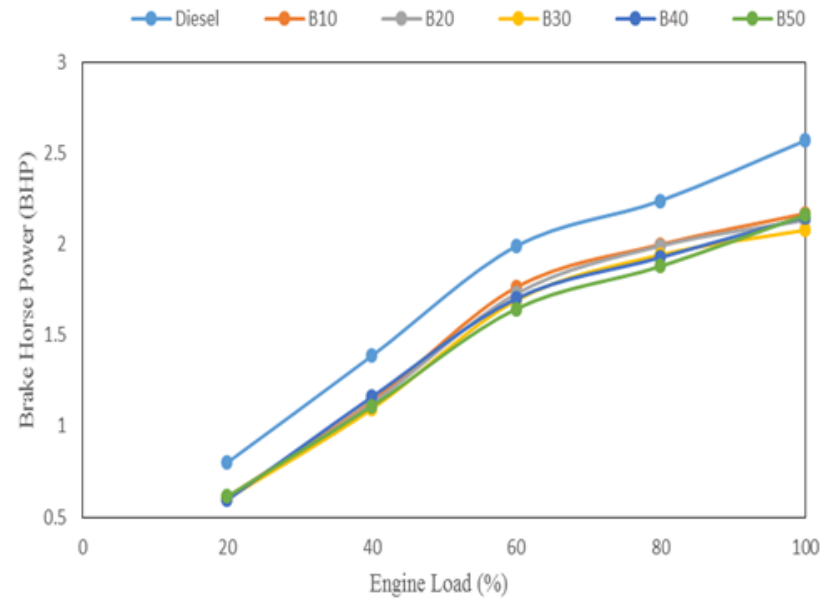

Fig. 5. Load vs Brake Horse Power

\section{E. Load vs Brake Specific Fuel Consumption}

Bsfc values for diesel, B10, B20, B30, B40 and B50 are 0.307, $0.334,0.325,0.342,0.342$ and $0.344 \mathrm{~kg} / \mathrm{kw} . \mathrm{hr}$. Data shows that at higher load B20 values are very close to that of Diesel.

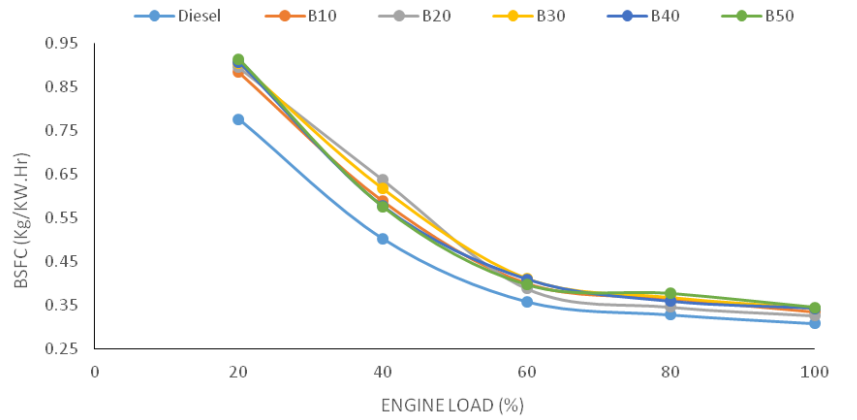

Fig. 6. Load vs Brake Specific Fuel Consumption

\section{F. Load vs Exhaust Gas Temperature}

Temperature value for diesel, B10, B20, B30, B40 and B50 are $275,221,212,192,183$ and $179^{\circ} \mathrm{C}$. As shown the Exhaust gas temperature increases with increase in brake power for all the tested fuels.

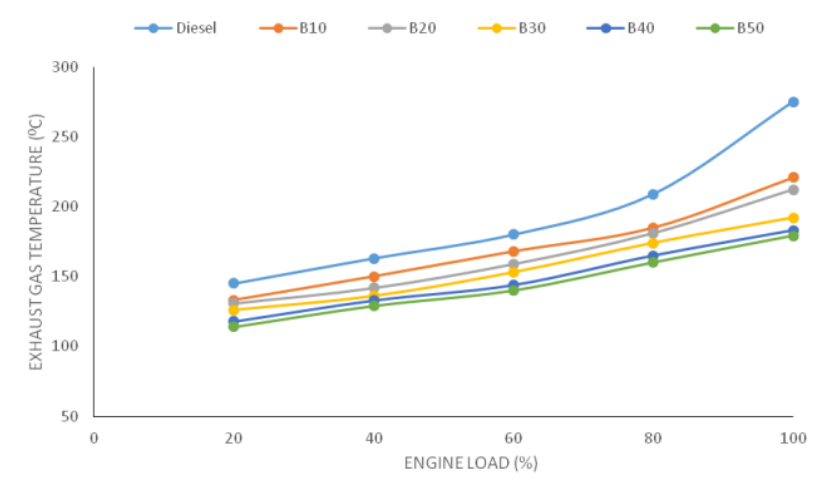

Fig. 7. Load vs Exhaust Gas Temperature

\section{CONCLUSION}

The exhaust emission and performance characteristics of blends are evaluated and compared with diesel. The experimental results prove that the ternary blends of Karanja methyl ester, Neem methyl ester and diesel oil can be used in 
diesel engine as fuel.

\section{REFERENCES}

[1] Tonkin I, Global biodiesel production reaches record high, 2009.

[2] Energy BSR of W. Statistical Review of World Energy, 2014

[3] International Energy Agency (IEA), World Energy Outlook, 2012.

[4] Roser M. Energy Production \& changing Energy Sources, Our World Data, 2014.

[5] IMF world economic outlood (WEO) update; January, 2016.

[6] No SY, Inedible vegetable oils and their derivatives for alternative diesel fuels in CI engines: a review, Renewable and Sustainable Energy Reviews, vol. 15(1), pp. 131-49, 2011.

[7] Nabi MN, Hoque SMN., Akhter MS, Karanja (Pongamia Pinnata) biodiesel production in Bangladesh, characterisation of karanja biodiesel $\&$ its effect on diesel emissions, Fuel Processing Technology, vol. 90, pp. 1080-1086, 2009.

[8] Gupta KR, Panesar BS, Thapar VK, Parametric studies on bio-diesel prepared from rice bran oil, Agricultural Engineering International: the CIGR Journal of Scientific Research and Development, vol. IX (EE 06 007), 2007.

[9] Prakash N, Jose AA, Devanesan MG, Viruthagiri T, Optimization of Karanja oil Trans-esterification, Indian Journal of Chemical Technology, vol. 13(5), pp.505-9, 2006.

[10] Heywood, J. B. (1988). Internal combustion engine fundamentals (Vol. 930). New York: Mcgraw-hill.

[11] Ganesan, V. (2012). Internal combustion engines. McGraw Hill Education (India) Pvt Ltd

[12] Sharma D, Soni SL, Mathur J, Emission reduction in a direct injection diesel engine fueled by neem-diesel blend, Energy Sources, Part A: Recovery, Utilization, and Environmental Effects, vol. 31, pp. 500-8, 2009

[13] Demirbas A, Progress and reent trends in biodiesel fuels, Energy conversion and Management, vol .50, pp 14-34,2009.

[14] Fangrui Ma, Hanna MA, Biodiesel Production: A Review, Bio resource Technology, vol 70, pp. 1-15, 1999.

[15] Mrad N, Varuvel EG, Tazerout M, Aloui F, Effects of biofuel from fish oil industrial residue-diesel blends in diesel engine, Energy, vol. 44, pp. 955-63, 2012.

[16] Baiju B, Naik MK, Das LM, A comparative evaluation of compression ignition engine characteristics using methyl and ethyl esters of karanja oil, Renewable Energy, vol. 34, pp. 1616-21, 2009.

[17] Patil PD, Deng S, Optimization of biodiesel production from edible and non-edible vegetable oils, fuel, vol. 88, pp. 1302-1306, 2007.

[18] Ashish Jawalkar1, Kalyan Mahantesh1, M Jagadish (2012). Performance and Emission Characteristics of Mahua and Linseed Biodiesel Operated at Varying Injection Pressures on CI Engine, International Journal of Modern Engineering Research (IJMER), 2, Page 1142-1149. 